\title{
Retirement and the Pension Crisis
}

In many countries the state pension age is rising. ${ }^{1}$ Governments often present this as a reflection of increasing life expectancy, and the need to extend working lives beyond traditional retirement ages, with individuals choosing, and also being required by law, to work longer. Indeed, in the UK, government has also stressed that increases in life expectancy presents them with no alternative other than to increase labour market participation of older workers. ${ }^{2}$ As a result of this increase, the role of flexible working practices in providing a route for older workers with the ability to make choices regarding how long they choose to engage in work related tasks ${ }^{3}$ has become important and widely discussed. These working practices have often been held up as a way to improve employment choices for older workers ${ }^{4}$, or provide bridge jobs to ease older workers into retirement. ${ }^{5}$ Indeed, the DWP have also identified this type of work as providing older workers with a choice where they may opt for a phased approach to retirement. ${ }^{6}$ This has led to the suggestions that retirement is no longer seen as a life defining event where workers leave the labour market for the final time, but instead a reversible state. ${ }^{7}$ Moreover, research has demonstrated that 'financial security' is key in retirement planning ${ }^{8}$, suggesting that whilst it may be a choice to work past retirement, for those who have worked in low pay occupations where there is poor pension coverage, it may represent compulsion. ${ }^{9}$ This may well be the case, as whilst we have seen increases in employment rates in the over 50 s and over $60 \mathrm{~s}$ it is worth noting that this increase has been in full-time work, not part-time work. ${ }^{10}$ This suggests that people are simply staying in the labour market longer, rather than bridging their way into retirement or 'un-retiring' via the use of flexible working practices. Thus, we have a growing life expectancy that has encouraged government to pursue a policy of increasing labour market participation of older workers, alongside decreasing access to occupational pension provision. ${ }^{11}$ Despite the importance placed on the role of flexibility by government and policy makers, research has revealed that when interviewed, older workers

\footnotetext{
${ }^{1}$ OECD, Pensions at a Glance (Paris: OECD Publishing, 2011).

${ }^{2}$ DWP, A New Deal for Welfare: Empowering People to Work (Cm 6730, London: The Stationary Office, 2006).

${ }^{3}$ E. J Hill, J. G. Grzywacz, S. Allen, V. L. Blanchard, C. Matz-Cpasta, S. Shulkin, 'Defining and Conceptualizing Workplace Flexibility’, Community, Work and Family, 11(2), 2008, pp.149-63.

${ }^{4}$ W. Loretto, S. Vickerstaff, \& P. White, Older Workers and the options for Flexible Work. (Working Paper Serier no. 31. London: Equal Opportunities Commission 2005); W. Loretto, S. Vickerstaff, \& P. White, 'Flexible Work and Older Workers', in W. Loretto, \& S. Vickerstaff, \& P. White, (eds.) The Future for Older Workers: New Perspectives, (Bristol: The Policy Press, 2007) pp.139-160.

${ }^{5}$ W. Loretto et al, 'Older Workers'; S. Vickerstaff, 'Older Workers: the unavoidable obligation of extending our working lives?’, Sociology Compass, 4(10), 2010, pp. 867-879.

${ }^{6}$ DWP, A New Deal for Welfare: Empowering People to Work , Cm 6730, London: The Stationary Office, 2006, p.139; W. Loretto, \& S. Vickerstaff, 'Gender, age and flexible working in later life', Work, Employment and Society, 29(2), 2015, pp.233-249.

${ }^{7}$ N. Maestas, 'Back to Work Expectations and Realizations of Work after Retirement', Journal of Human Resrouces, 45(3), 2010, pp. 718-748.

${ }^{8}$ C. Price, 'Professional Women's Retirement Adjustment: the experience of re-establishing order', Journal of Aging Studies, 17, 2003, pp. 341-355.

${ }^{9} \mathrm{~V}$. Beck, \& G. Williams, 'The (performance) management of retirement and the limits of individual choice', Work, Employment and Society, 29(2), 2015, pp.250-267.

${ }^{10}$ ONS, Older Workers and the Labour Market, 2012; ONS, Pension Trends 2013 Edition, 2013; Loretto and Vickerstaff, 'Gender, age and flexible working'.

${ }^{11}$ J. Grady 'Trade Unions and the Pension Crisis: Defending Member Interests in a Neoliberal World', Employee Relations, 35(3), 2013, pp.94-308.
} 
expressed the desire to reject flexible work ${ }^{12}$, much of which is characterised by low pay/skill with few prospects. Loretto and Vickerstaff have also demonstrated that amongst older and retired workers there is actually a feeling of 'release' that accompanies retirement, suggesting that individuals on the whole wish to be free from the labour market, and 'get off the treadmill' once they have 'done their bit'. ${ }^{13}$ This research challenges the agenda of extending working lives, suggesting that, for many, people are looking forward to ending paid employment where such a choice is possible.

What this chapter discusses is not the extent to which older workers wish to engage with the labour market beyond state pension age - other contributions to this volume engage with that - but rather asks question about how the crisis, as a continued crisis in provision, coupled with a low income in both working years and later life, will compel many to work beyond traditional state pension age, as pensioner poverty increases, and the value of pensions decrease. As such it contributes to debates regarding choice or compulsion, as it is argued that unless we enact sustainable pension provision with adequate income in retirement more individuals will be compelled to work in old age due to the increase in low paid work, an increase use in zero hour contracts, closure of occupational schemes, and inadequate state pension provision. With specific reference to the later two, this chapter will examine how the pension crisis has been framed, and suggest that this dominant narrative is misleading. Moreover it will then explore how the proposed solutions to the UK pension crisis will not provide adequate pensions for those it is intended to; the New Auto-enrolment pension will be directly discussed. In short therefore, it places the debates surrounding active ageing in a very important context, namely that of the pension crisis that will compel many to engage with paid employment, whether or not they wish to. Active ageing, therefore, is less of a choice for many, but may become a typical requirement.

Obvious questions may seem to be how will we engage people in the labour market past traditional retirement ages, how we will ensure fair access to work with dignity, and how we will enable this? However, if what we are witnessing actually is people working beyond the retirement age because they are compelled to, then we need to understand the role of the pension crisis in this. Indeed, we need to ensure people have access to good pension provision, rather than access to work after retirement. With that argument in mind, this chapter turns its attention to the pension crisis, and demonstrates that the dominant understanding of the pension crisis is misleading. By demonstrating this, it argues that other solutions are possible than those currently posed, whilst also arguing that current proposed policy will not have the promised impact of solving the pension crisis; rather, it will perpetuate a problem of state underfunding and short termism regarding pension planning.

This chapter ties together themes from various literatures in order to advance a new understanding of the pension crisis. To engage with this synthesis, it is first necessary to analyse the constituent parts of the literatures that have given rise to it. A review of this literature that is orientated

\footnotetext{
${ }^{12}$ D. Lain, 'Working past 65 in the UK and the USA: segregation into 'Lopaq' occupations?', Work, Employment and Society, 26(1), 2012, pp. 78-94; W. Loretto, \& S. Vickerstaff, Gender, age and flexible working, 2015.

${ }^{13}$ Loretto and Vickerstaff, ‘Gender, age and flexible working’, pp.239-240.
} 
towards developing an understanding of the ideological aspects of the pension crisis reveals swiftly the utility of linking together various approaches to neoliberalism, pensions, and labour organisation in order to present an account of the pension crisis that runs contrary to the hegemonic one now dominant. This alternative account can be used as a lens through which to analyse the challenges that the dominance of neoliberal ideology has presented not only for pensions. Thus it allows us to examine the growing dominance of neoliberal ideology, and in doing so to ask why it has been so difficult to challenge neoliberal hegemony. Finally, we begin to understand better the push for people to work past retirement age as being linked to adequacy of pensions.

To accomplish the above, the remainder of this chapter is structured thus: (i) a discussion of neoliberalism and the ways in which neoliberal ideology has been naturalised; (ii) a thorough analysis of the pension crisis (as represented both through conventional and alternative accounts); and (iii) a discussion of New Labour's neoliberal turn and how trade unions have responded to it.

\section{The Role of Neoliberal Ideology and Discourse}

The concept of ideology provides an alternative analysis of the pension crisis. In short it argues that the pension crisis, as widely understood in the UK, is based on a number of misleading and/or narrow discourses. Building on the argument put forward elsewhere (Grady 2010; 2013), it is argued that the dominant (hegemonic) narrative of the pension crisis is based on a neoliberal construction of the crisis (rather than upon empirical fact), and that this construct is supported by a number of narrow, and often misleading, discourses In addition it is also argued that these discourses are constructed for, and work towards, ideological ends, principally the support of neoliberalism which represents contemporary capitalism's ruling ideology.

According to Thompson ${ }^{14}$, dominant social group or classes can use ideology to legitimate their dominance. Thus for Thompson, to study ideology is to study the ways in which meaning (or signification) serves to sustain relations of domination, and it is this understanding of ideology in relation to neoliberal ideology that this chapter employs. Furthermore, Eagleton ${ }^{15}$ outlines the process through which ideologies are legitimated and argues that a dominant power may legitimate itself through six different strategies. A dominant power may legitimate itself by (1) promoting values and beliefs congenial to it; (2) naturalizing and, (3) universalizing such beliefs so as to render them self-evident and apparently inevitable; (4) denigrating ideas which might challenge it; (5) excluding rival forms of thought, perhaps by some unspoken but systematic logic [in terms of neoliberalism this is the often unspoken, but yet so often tacitly applied, logic of the market]; and (6) obscuring social reality in ways convenient to itself. This chapter uses the understanding put forward by Thompson, and the strategies outlined by Eagleton to argue that neoliberalism performs as an ideology, and legitimates itself. Discourses and misleading narratives are deployed to achieve these strategies, and therefore act as an ideological vehicle to further legitimate neoliberal values, and serve those elites who best benefit from them.

\footnotetext{
${ }^{14}$ J. B. Thompson, Ideology and Modern Culture: Critical Social Theory in the Era of Mass Communication, (Cambridge: Polity Press, 1990).

${ }^{15}$ T. Eagleton, Ideology: An Introduction, (London: Verso, 1991, pp.5-6).
} 
Neoliberal ideology is, therefore, linked to power and to domination: power to control the terms of the discourse, and power, therefore, to dominate the social world. In this sense the pension crisis is transformed into more than merely a crisis regarding pension provision. It becomes a site where those seeking neoliberal reform of pension provision seek to construct and exploit a crisis in order to enact urgent reform. In other words, a crisis is constructed to which the obvious remedial steps are those consistent with the dominant neoliberal ideologies that run through contemporary capitalism. ${ }^{16}$ This chapter maintains that neoliberal discourses represent the 'official' narrative regarding the pension crisis. In that context, neoliberal solutions - privatisation and individualisation - are offered and seem, at first glance, to be natural solutions to the crisis.

Further to the above, Jessop ${ }^{17}$ argues that whilst all discourses are equal, some are more equal than others. Indeed, some discourses are able to reach the stage of naturalization whilst others do not. ${ }^{18}$ This helps us to understand why neoliberal discourses have formed the conventional narrative of the pension crisis, it is precisely because such discourses have become naturalised. Earlier work $^{19}$ (identified the dominance of three main discourses (ageing, affordability, and responsibility) that are presented as explanations of the causes of the pension crisis. These discourses frame not only the terms of the debate, but also the potential solutions. In that chapter, it was argued that whilst those discourses contain empirical truths, the way in which the evidence they contain is presented construes the pension crisis to be the consequence of a certain set of slim factors. In doing so, it ignores factors that either contradict or challenge this construct of the crisis, factors which might suggest a solution other than a neoliberal one. Thus an alternative account of the pension crisis was offered, one that argued the conventional and hegemonic account, whilst not necessarily false, is certainly misleading. In short, the ideological discourses put forward to account for the pension crisis are true on one level, but they are not on another. Thus, they are true in their empirical content but deceptive in their force. ${ }^{20}$ It is precisely for this reason that it is argued that those with a neoliberal agenda offer these discourses ideologically and aggressively in order to favour neoliberal pension reform. First, the nature of the crisis is manipulated through presentation and this presentation is then exploited as a justification of urgent and radical reform along free-market principles. Such reforms create yet further investment opportunities for the economic elite. Indeed, we have seen this before during the Thatcher governments.

It is, of course, worth nothing here that, herein, discourses are not only considered to be ways of representing the world, but also to be ways of influencing the world. ${ }^{21}$ What is said or written can causally influence what we subsequently do. This makes discourse a potential cause of social action. Discourse influences action by selecting and emphasising certain linguistic, and hence practical possibilities, whilst deselecting, de-emphasising or excluding others; thus, the former are far more

\footnotetext{
${ }^{16}$ P. Pierson, Dismantling the Welfare State: Regan, Thatcher and the Politics of Retrenchment (Cambridge: Cambridge University Press, 1994).

${ }^{17}$ B. Jessop, The Cultural Political Economy of Crisis, paper presented at Leicester Business School,

Demontfort University Department of Public Policy/Local Governance Research Unit Seminar Series, 2010.

${ }^{18}$ Eagleton, Ideology, 1991, p. 200.

${ }^{19}$ Grady, 'Trade Unions and the Pension Crisis’; J. Grady, 'From Beveridge to Turner: Laissez-faire to Neoliberalism', Capital and Class, June, 2010, pp. 163-180.

${ }^{20}$ Eagleton, Ideology, 1991, pp. 16-17

${ }^{21}$ N. Fairclough, Analysing Discourse: Textual Analysis for Social Research (London: Routledge, 2003).
} 
likely to occur. Therefore it is important to point out that just because discourse can 'construe' the world, it does not mean that discourse can re-construct the world. Remembering this allows us to retain the notion that what we say or write about practices related to pension provision can have causal efficacy, without lapsing into an idealist trap whereby what we say or write creates or constructs these practices. Put simply, by selecting and emphasising certain linguistic (and hence action) possibilities and de-selecting, de-emphasising or excluding others, some discourses relating to pension provision may become accepted as true-even if they are false. ${ }^{22}$ Indeed, below, it will be argued that being forced to interact with these dominant discourses (even if they are recognised as fake) acts to legitimate their status.

Within the field of Employee Relations there has been much written about pensions and the pension crisis. Many of these works have discussed employee perceptions of pension schemes ${ }^{23}$; pension scheme membership and its impact on employee retention rates ${ }^{24}$; power asymmetry in accessing the law in relation to pension schemes ${ }^{25}$; pensions and industrial conflict ${ }^{26}$; and, amongst other issues, international pension comparisons. ${ }^{27}$ They all put forward important contributions in opening up the debate about pensions as part of the employment relationship, and provide access to a subject that is often (due to the technical nature of some terms) daunting to the average person.

This section will analyse in more detail the significant changes to pension provision that occurred from the late 1980s onwards, and will demonstrate that these changes reflect a neoliberalisation of pension provision, and further that it is this process of neoliberalisation that has in fact caused the current crisis, despite the conventional accounts claiming the contrary. It will be argued that the hegemonic construct of the crisis - as presented by the use of key discourses - is an artificial crisis. This is not to say that there is not a crisis of some form in relation to continued pension provision. Not only are 2 million pensioners due to retire into poverty ${ }^{28}$ but also increased life expectancy means that issues such as the cost of schemes and age of retirement do need addressing. It needs to be considered however, the extent to which these legitimate questions are actually answered satisfactorily by conventional pension debates, and the extent to which they are simply exploited to reform pension provision along neoliberal, free-market lines.

\section{A Brief Overview of Current Pension Provision in the UK}

\footnotetext{
${ }^{22}$ S. Fleetwood, 'Ontology in Organization and Management Studies: A Critical Realist Perspective’, Organization 12, 2005, p. 200.

${ }^{23}$ W. Loretto, P. White, \& C. Duncan, 'Something for nothing?: Employees' views of occupational pension schemes', Employee Relations, 22 (3), 2000, pp: 260-271; O. Gough, \& R. Hick, 'Employee evaluations of occupational pensions', Employee Relations, 31(2), 2009, pp: 158-167.

${ }^{24}$ S. Taylor, 'Occupational pensions and employee retention: Debate and evidence', Employee Relations, 22 (3) 2000, pp 246-259.

${ }^{25}$ R. Nobles, 'Access to the law of pensions: The lessons from National Grid v. Laws', Employee Relations, 22 (3), 2000, pp. 282-285.

${ }^{26}$ C. Nolda, 'Industrial conflict in local government since', Employee Relations, 199726 (4), 2004, pp. 377-391.

${ }^{27}$ D. Cooper, 'A tale of two pension systems', Employee Relations, 22 (3), 2000, pp. 286 - 292.

${ }^{28} \mathrm{H}$. Osbourne, '2m pensions live in poverty says ONS', The Guardian, 27 January 2010.
} 
The argument that pension provision has been subject to neoliberal attacks is not a new one and has been put forward by a number of authors writing about a variety of countries and contexts. ${ }^{29}$ However, prior to the onset of the pension crisis in the late 1990s and the early 2000s pensions rarely made the news and interest in them tended to be the preserve of statisticians and actuaries. This has obscured the central significance that pensions hold. Given the scope of this chapter, only a brief overview of the UK pension crisis, as widely understood, can be presented. Once this conventional account is established, it will be explored what is referred to in this chapter as the 'real' pension crisis, and thus expose how the conventional crisis is in actual fact an artificial crisis.

It is accurate to state that historically in the UK we have a pension system that has relied upon individuals having access to a pension scheme other than the British State Pension (BSP). Indeed, in 2007 the BSP represented just 15.9 per cent of average wages. Hence, for many people in employment, workplace-based, collective pension schemes supplemented their incomes after retirement. Traditionally this sort of scheme would be a 'final salary' defined benefit (DB) scheme, which was contributed to by both employer and employee. A working life of contributing to such schemes usually provided adequate income in old age. The closure of these schemes in favour of money purchase defined contribution (DC) schemes, or simply encouragement for employees to make their own pension arrangements, has left a significant number of workers without guaranteed and secure pension entitlement. This has caused a crisis of access to secure pension provision, and therefore, retirement income and has resulted in more people relying on state provision as their only form of income in retirement. Without a commitment to improving alternative saving options, and ensuring they offer a guaranteed income in retirement (which neither the now abandoned NESTs - National Employment Savings Trusts - nor the new Auto-Enrolment pensions will), this is only set to continue.

The demise of DB schemes, and their replacement by less secure and schemes funded by riskier investments, has revealed the inability of current pension arrangements to provide a decent and guaranteed retirement income. For those who have access to them, DB schemes provide a pension upon retirement based on years of service and salary at time of retirement. Members of DB schemes usually accrue $1 / 60$ th or $1 / 80$ th per year of service.

An additional factor related to DB schemes has helped to create the perceived pension crisis is that of pension contribution holidays. It has been generally been the case that 70 per cent of the value of any DB scheme will be invested in the stock market and the rest to be mainly in gilts, corporate bonds (company versions of gilts), and property. The returns on these investments act as the determining factor on which the liquidity and solvency of the scheme as a whole is based. As such, in principle and if the returns are high, the employer can enjoy lower contributions so long as they

\footnotetext{
${ }^{29}$ M. Townson, The Social contract for Seniors in Canada: Preparing for the $21^{\text {st }}$ Century, (Ottawa: National Advisory Council on Ageing, 1994); R. Minns, The Cold War in Welfare: Stock Markets Verses Pensions, (London: Verso, 2001); R. Blackburn, Banking on Death or Investing in Life: the history and future of pensions, (London: Verso, 2002); J. Williamson, \& M. Williams, 'Notional Defined Contribution Account Neoliberal Ideology and the Political Economy of Pension Reform', American Journal of Economics and Sociology, vol. 64, no. 2, 2005, pp. 485-506; J. Morgan, 'The UK pension system: the betrayal by New Labour in its neoliberal global context’, Research in Political Economy, vol. 23, 2005.
} 
maintain a solvent scheme that covers its liabilities. These lower contributions are also known as 'contribution holidays'. Contribution holidays, however, can only be taken by Company DB schemes. For occupational DB schemes such as University Superannuation Scheme or the LGPS (local government pension scheme) the employer has a contractual obligation to pay contributions, making contribution holidays illegal. The implications of pension holidays for the creation of the pension crisis is discussed below.

\subsection{The Manufacturing of a Pensions Crisis}

This section will provide a brief summary of how instabilities were introduced into the pension system and thus provide the basis for the central argument of this chapter; that the conventional construct of the pension crisis is misleading. Dissecting this construct is difficult, nevertheless the work of Jamie Morgan is indispensable in helping us to see in broad perspective the ways in which the pension crisis has been constructed. The first potentially 'crisis causing' event for final salary schemes happened prior to the election of New Labour, and was the introduction of the 5 per cent tax cap on DB pensions schemes introduced by the Conservative Chancellor of the Exchequer, Nigel Lawson, in the 1986 Finance Act. The Act imposed a 5 per cent cap on the value of assets over liabilities in DB pension schemes; any surplus is now subject to heavy taxation. This new tax cap was designed to deter organisations from tax avoidance by making large contributions to the company pension scheme in high profit years.

The problems that the 1986 Act caused were not immediately obvious. ${ }^{30}$ Nevertheless, simply staying within the cap, and avoiding paying tax, became the motivation for organisations; not maintaining a healthy, and slump-proof, pension scheme. Morgan also points out that the new tax cap allowed organisations to decide how to distribute the 'benefits of the capital which would exceed that cap'. ${ }^{31}$ It is unsurprising that CEO's now chose to pay higher dividends, rather than to improve pensions as they had done heretofore. Larger dividends improve the attractiveness of equities and in turn these enhance share prices, as such they are immediately appealing. By contrast, attempting to carry on contributing to pension schemes by investing above the five per cent cap would attract heavy taxation on those contributions, needless to say companies were keen to avoid increasing their tax liabilities. The impact of contribution holidays is often left out of the hegemonic pension 'crisis' narrative; indeed, it is not even mentioned in either of Lord Turner's Reports on the state of pensions in Britain which were commissioned by New Labour and which form the basis of the state's response to the pension crisis. ${ }^{32}$

Neglecting the importance of employer contribution holidays hides the nature of the artificial crisis identified here, and in more detail by Morgan. ${ }^{33}$ Employers who have closed, or who are considering to close schemes, often cite the inherent instability and crippling unaffordability of final salary schemes, whist quietly passing over the large deficits left by contribution holidays. For example, British Airways, who enjoyed a sustained period of contribution holidays in the 1990s, accrued a $£ 3.7$

\footnotetext{
${ }^{30}$ Morgan, The UK pension system, 2005, p. 319.

${ }^{31}$ Ibid.

32 J. A. Turner, The Pension Commission: Challenges and Choices, (London: HMSO, 2005); J.A Turner The

Pension Commission: A New Pensions Settlement for the Twenty-First Century, (London, HMSO, 2006)

${ }^{33}$ Morgan, The UK pension system, 2005, p.319.
} 
billion pension scheme deficit. In 2003, the company closed their scheme to new members citing rising costs related to deficit reduction as the cause. BA claimed that the long-term viability of the scheme was in jeopardy if employees did not comply with the changes. But this account conceals the importance of key events (such as contribution holidays) that have led to the deficit. It does so by focussing on the discourse of affordability and responsibility, principally of the employee to the company rather than the other way around. The BA case is not unique.

In addition to contribution holidays, in 1997, as part of his first budget as Chancellor of the Exchequer, Gordon Brown abolished the dividend tax credit (DTC) for pension schemes. Morgan ${ }^{34}$ argues that this new tax regime introduced by Brown ensured a quicker downturn in DB schemes; the thrust being that Brown's legislation exacerbated the problems that Lawson had introduced to workplace pension schemes and worsened the potential for a pension's crisis. Employers used the increased instability this created as an excuse for reforms to pension schemes that were profitable to them. Brown's legislative changes made matters worse in two ways. First, schemes were liable to tax on returns on equity investments established by Brown's law. Second, schemes were liable to taxation on total asset valuation if the 5 per cent cap was exceeded (Lawson's law). The abolition of DTC effectively increased the cost of maintaining a solvent pension scheme overnight. The abolition of the $\mathrm{DTC}^{35}$ in isolation would have been a perfectly justifiable action for a Labour government, particularly if the revenue raised from the taxation had gone to pensioners, and if it had been 'followed up with measures to make the funds accountable to social and economic priorities'. ${ }^{36}$ However, this was not the case. Indeed, in the March 2000 budget the BSP was increased by only 75 pence, a sum that, it was remarked upon at the time by pensioners, would only cover the price of a packet of peanuts.

To make matters worse for potentially vulnerable pension schemes, the firms that were most affected by the abolition of the DTC were those that had become accustomed to taking contribution holidays. As we have seen, such behaviour was encouraged by Lawson's tax cap. In short, the two laws, when combined, made more likely a potential pension crisis by encouraging irresponsible and short-termist behaviour by corporations, and by fundamentally contradicting each other. It is also the case that neither tax channelled additional revenue to help pensioners. Instead, the BSP was allowed to decline.

Recognition of the instabilities that Lawson and Brown introduced to pension schemes is necessary if one is to fully understand the nature of the crisis facing DB schemes, and the neoliberal arguments presented in the face of this crisis. The dominant pension crisis narrative (endorsed by both Turner Reports) ignored the impact of Lawson and Brown's respective roles as Chancellor of the Exchequer and the important role that their respective taxation reforms to pension schemes have played in destabilising and then magnifying these instabilities. It also ignored how willing employers were to exploit the impact of these instabilities in order to accelerate the closure of schemes. As such it will be argued that the pension crisis in DB schemes is a manufactured (artificial) crisis that has been caused, rather than a 'naturally' occurring crisis as is so often the case presented by the hegemonic discourse.

\footnotetext{
${ }^{34}$ Ibid.

${ }^{35}$ Blackburn, Banking on Death , 2002, p.316.

${ }^{36}$ Ibid.
} 
In addition to the above, very substantial factors that have contributed towards a downturn in DB schemes, other factors made matters worse. The new tax regimes depended upon, and were modelled upon the existence of, a sustained bull market (within which share prices are rising, which encourages buying). This in turn meant that the whole system of DB schemes also became susceptible to market volatility. Indeed the very instabilities referred to above are these instabilities - the inherent instability of directly linking the solvency of a scheme to the maintenance of a bull market. This was an astoundingly short-term perspective ${ }^{37}$ that ignored the historical development of capitalism, which has consistently demonstrated that by their very nature markets are volatile.

Unsurprisingly, these conditions presented employers with difficult choices and it is hardly surprising that employers began to question their financial commitment to a DB pension scheme with many investigating less-costly pension alternatives. It must be stressed here that DB pension schemes are not necessarily inherently unstable, as is often presented. By examining in detail the various tax regimes, and irresponsible behaviour it encouraged, it can be demonstrated that this pension crisis is not a naturally occurring facet of DB schemes. The neoliberal discourse of unavoidable crisis is one that employers are happy enough to use as it has meant that they can abandon their commitment to these types of schemes which are the most expensive to maintain because they do require longterm commitment to something other than maintaining share dividends. Moreover some organisations were in serious deficits, and employers were able to exert a considerable amount of moral blackmail on employees who were called upon to help save the company rather than pursue their pension entitlements. In short, employees were expected to absorb the reckless behaviour of their employers by accepting a lower standard of pension and be thankful things were not worse.

In addition, vulnerabilities exploited by the end to tax dividend credit were further intensified by the introduction of FRS17 (financial reporting standard 17) accounting procedures for DB pension schemes. Unlike previous accounting procedures that produced an overly optimistic view of asset valuation based on a long-term prediction of past stock market performance, FSR17 did not flatten out fluctuations into long-term growth, and the new calculation of schemes assets and liabilities meant that further vulnerabilities were introduced into an already over-exposed system. Originally intended to be phased in over a three-year period, FRS17 (introduced by the non-government Accounting Standards Board) exposed the extent of underfunding of schemes, and the subsequent shortfalls and forced organisations to 'face-up-to' shortfalls and deficits. Combined with the above, the introduction of FRS17 was to have the effect of persuading firms to close their DB schemes in favour of less secure schemes such as DC.

The introduction of DC schemes (along with other inferior pension saving arrangements such Stakeholder Pensions, the proposed and now defunct Personal Accounts, and the soon to be introduced auto-enrolment), as a replacement for DB schemes, has represented a decrease in the quality of pension provision for employees. Employers who have closed their DB schemes contribute little or nothing to the new DC and Stakeholder Pensions, and by the very definition of 'defined contribution' (DC), these pensions offer no guarantee of retirement income. Indeed, we know that the 'low-cost' stakeholder pension has produced miserable returns for savers. Indeed, Collinson ${ }^{38}$ calculated this year that those who saved $f 100$ a month from April 2001 (thus paying in

\footnotetext{
${ }^{37}$ Morgan, The UK pension system, 2005, p.321.

${ }^{38}$ P. Collinson 'We Need to Order a Danish Pension', The Guardian, 13 July 2012.
} 
total $f 13,300$ ) have only accumulated $£ 14,600$ eleven years later (April 2012). Savers would have been better investing in a cash ISA rather than a government backed Stakeholder pension.

It was, therefore, the combination of systematically irresponsible tax regimes from the Chancellors of both major political parties; the greediness of employers who are willing to enjoy the benefits of the stock market in good times by taking contribution holidays, but who were not willing accept the consequences of their actions in economic downturns; and the introduction of a new accountancy procedure, the FRS17, that led to the wholesale closure of DB schemes, either entirely or else to new members. Conventional explanations (that reflect neoliberal ideology and the neoliberal construct of the crisis) cite the inherent instabilities of DB schemes that were somehow responsible for their own 'downfall'. As we have seen, this understanding is not merely oversimplified but is in fact incorrect. The move away from DB schemes was also an implicit recognition by employers that the need to offer attractive benefits such a long-term DB pension provision was not longer necessary to attract and retain employees. Given that we know financial planning is key to retirement planning ${ }^{39}$ the pension crisis, as outlined above has left many with inadequate pensions, thus we can expect to see many compelled to remain in the labour market to augment this shortfall. This is a very different narrative to that of choice to engage with flexible working practices and extension of working lives as a bridge as we have seen outlined elsewhere.

\section{New Policy Changes}

In response to the 'crisis' outlined above, new pension policy has been enacted, Auto-Enrolment pensions. Space precludes discussion of the increases in retirement age, and given the focus of this this change is discussed in more detail by others in this collection. It will also provide a brief outline of stated aims of Auto-Enrolment, as it is suggested that this policy represents an improvement on previous state-led arrangements ${ }^{40}$, whilst also providing solutions to the pension crisis. As was demonstrated in the previous section, it will be argued here that an alternative analysis of the pension crisis helps us question the extent to which new policies will actually solve the crisis.

Traditionally the UK had a three tiered pension system: Tier 1 , basic state provision provided via taxation; Tier 2, additional (opt-in) earnings-related state provision; and Tier 3, private provision (occupational or personal pension). Thus Tiers 1 and 2 were state funded, and Tier 3 privately funded. In May 2014, Parliament passed the Pensions Act (2014), which introduced a new flat-rate State Pension for people reaching State Pension Age on or after 6 April 2016. In addition to this change, the Pension Act (2008) heralded the introduction and implementation of Auto-Enrolment pensions (a private and public partnership workplace pension) in October 2012. The Pensions Act (2014) also included provisions for an increase in the age at which people would be eligible for the State Pension, though there is insufficient space to discuss these proposals at any length here.

Since the introduction of Auto-Enrolment pensions, government has made it policy that those who reach state pension age on or after 6 April 2016 will no longer be eligible for additional state

\footnotetext{
${ }^{39}$ Price, 'Professional Women’s Retirement Adjustment', 2003.

${ }^{40} \mathrm{~S}$. Webb 'Pensions minister Steve Webb on welfare reforms - video, The Guardian, 2013, available at: http://www.theguardian.com/politics/video/2013/apr/01/pensions-minister-steve-webb-welfare-reforms-video, [accessed: 1 August 2015].
} 
pension, and thus it is being phased out. Instead, the Basic State Pension (Tier 1) will provide all state only provision. Thus, after 2016 the three Tier pension system that will be arranged accordingly: New Tier 1) state public pension provided via taxation; New Tier 2) public/private partnership of individualised savings; New Tier 3) Individualised private occupational provision. This represents a significant shift and restructuring of the provision of pensions in the UK, and a move towards a more marketised and individualised savings regime.

Auto-Enrolment pensions are available to all workers aged between 22 and the State Pension Age so long as they earn the required salary threshold, currently $£ 10,000$. Employees are automatically enrolled into a pension scheme chosen by their employer but have the right to opt out. The required level of contribution is 8 per cent (employees contribute 4 per cent, employers contribute 3 per cent, and the government contributes 1 per cent). Like most workplace pensions some of it can be taken as a tax-free lump sum upon retirement. Twenty five per cent of the pension will be tax free, but Income Tax must be paid on the rest.

In a recent report from the Department of Work and Pensions (DWP) it has also been suggested that:

Automatic enrolment is proving significantly more successful than previously predicted. With opt outs remaining low we now expect 9 million people will be newly saving or saving more as a result of our reforms.

Our reforms to pensions are working and have already proved a success. Now this is an extra million savers who will be helping to secure a better future for them-selves and their families. ${ }^{41}$ (DWP 2014a)

Due to low opt-out figures, Auto-Enrolment pensions have been heralded by the government as a success with 4 million workers enrolled since their establishment. ${ }^{42}$ Membership of occupational pension schemes has traditionally been higher for men, so it is also expected that the introduction of Auto-Enrolment, open to all who earn over the threshold, will help address this imbalance, and bring women into workplace pension provision. As such Auto-Enrolment pensions has been welcomed by the Trades Union Congress, but concerns have also been raised about the suitability of AutoEnrolment for providing an adequate pension. ${ }^{43}$

\footnotetext{
${ }^{41}$ DWP, Press Release: Pension savings - 9 million newly saving or saving more, says Pensions Minister, available at: https://www.gov.uk/government/news/pensions-savings-9-million-newly-saving-or-saving-moresays-pensions-minister, [accessed: 1 August 2015] 2014a.

${ }^{42}$ J. Ugwumadu, 'Four million now auto-enrolled into workplace pensions', The Actuary, available at: http://www.theactuary.com/news/2014/08/four-million-now-auto-enrolled-into-workplace-pensions/2014 [accessed: 1 August 2015]/

${ }^{43}$ H. Osborne, 'Warning over poor performing auto-enrolment pensions', The Guardian,11 Oct 2012; PWC available at: http://pwc.blogs.com/scotland/2012/09/millennials-pensions-will-fall-short-of-todays-pensionersdespite-auto-enrolment.html [2012, accessed: 1 August 2015]; PPI What level of pension contribution is needed to obtain an adequate retirement income? Available at:

http://www.pensionspolicyinstitute.org.uk/publications/reports/what-level-of-pension-contribution-is-needed-toobtain-an-adequate-retirement-income [2013, accessed: 1 August 2015]; A. Uren,'The $12 \mathrm{mn}$ workers who risk retiring on inadequate incomes with middle earners hit hardest by a pensions shock', available at: http://www.thisismoney.co.uk/money/pensions/article-2418601/12m-working-adults-face-retiring-inadequateincomes.html, [2013, accessed: 1 August 2015]; H. Roberts availbe at: http://www.hrmagazine.co.uk/hro/news/1143906/staff-employers-concerned-retirement-savings, [2014a,
} 
An initial problem is that many of the poorest workers do not earn enough to qualify for Enrolment. Given that women are more likely to be low paid ${ }^{44}$, we see a higher proportion of women being excluded. But we also know that income is key in retirement planning, so this pension provision is less likely to help the lowest earners strategically save for their retirement, because they simple do not earn enough to begin with. As such, they ideally need assistance, rather than access to a scheme. In addition, even for those enrolled there are concerns that the value of the pension will not to deliver sustainable retirement incomes. ${ }^{45}$ The main cause of concern with Auto-Enrolment is that a contribution rate of 8 per cent is just too low. Indeed, the DWP acknowledge that someone earning $£ 28,900$ would need to put away $£ 3,250$ a year ( $11.2 \%$ of salary), to even have a chance of a comfortable retirement ${ }^{46}$ As Auto-Enrolment only requires 8 per cent contributions, this leaves a 3.2 per cent gap for this salary group. Given that the Auto-Enrolment threshold is $£ 10,000$ we can see this will be a particular problem for low earners, as not only will their pension be significantly smaller due to their low income but also it is less likely that they will have any spare income to save additional amounts over the 8 per cent minimum contribution. If the value of the pension is allowed to fall, then this is most likely to impact on low earners who are unable to save as much privately, or may be denied access to Auto-Enrolment. ${ }^{47}$

In addition, increased contributions from employees will not be matched with increased contributions from either employer or State, which leaves little incentive for very low earners to redirect salary to their pension pot. Thus, the Auto-Enrolment scheme is praised as a triumph because it offers access to workplace pension saving for many more people. However, as 8 per cent contributions are unlikely to provide a sufficient retirement income for savers, Auto-Enrolment provides the illusion of adequate pension provision, rather than the delivery of it. The likely outcome of Auto-Enrolment then, is increased working life as recipients will not be able to fully supplement their working income with their pension, thus further demonstrating that for some nonretirement may well be representative of coercion rather than personal choice.

The account of Auto-Enrolment advanced by government also suggests that a level playing field has been created because the ability to independently save has been extended to women. This is only part of the narrative for women, however. At the same time, the increasing costs of childcare will prolong female breaks from the labour market as more new mothers decide to stay at home or work part-time. ${ }^{48}$ This will additionally dilute the value paid into Auto-Enrolment pensions by women,

accessed: 1 August 2015]; H. Roberts http://www.hrmagazine.co.uk/hro/news/1146027/auto-enrolment-doesntprovide-decent-income-low-paid-workers-tuc [2014b, accessed: 1 August 2015]; TUC, 'Auto-enrolment pensions must do more for low-paid workers, says TUC, 2014’, http://www.tuc.org.uk/economicissues/pensions-and-retirement/auto-enrolment-pensions-must-do-more-low-paid-workers-says [accessed: 1 August 2015],

${ }^{44}$ M. Saari, 'Promoting Gender Equality without a Gender Perspective: Problem Representations of Equal Pay in Finland', Gender Work and Organization, 20(1), 2013 pp. 34-54; T. Warren 'A Privileged Pole? Diversity in Women’s Pay, Pensions and Wealth in Britain’, Gender Work and Organization, 10(5), 2003 pp. 605-628.

${ }^{45}$ PWC 2012; Uren, 'The 12mn workers'.

${ }^{46}$ K. Morley, 'Rethinking the Pension', Investors Chronicle, 23 January 2014, p.3.

${ }^{47}$ C. Saunders, 'Pot half full? How women lose out when it comes to pensions', The Guardian, 1 May 2013 available at: http://www.theguardian.com/women-in-leadership/2013/may/01/women-lose-out-on-pensions, [accessed 1 August 2015]; WRC 'Women's equality in the UK - A health check', CEDAW shadow report 2013, Women's Resource Centre, 2013.

${ }^{48}$ G. Cory \& V. Alakeson, 'The Resolution Foundation, Careers and Carers', 2014 available at: http://www.resolutionfoundation.org/media/media/downloads/Careers_and_Carers_FINAL.pdf [accessed: 1 August 2015]. 
further calling into question its suitability, which will obviously impact on the retirement choices of these workers when they are older, and indeed, may compel them into longer working lives.

It should be noted that Auto-Enrolment is accompanied by the introduction of the New Flat Rate State Pension, which is intended to simplify the existing complex system. It is also expected that a simpler and fairer system will make it easier for individuals to plan their retirement savings. The features that differentiate it from the old State Pension are that it will be worth more than the current basic State Pension and will be given to people with at least 35 years National Insurance contributions (NI) or credits. People will need at least 10 years of contributions to qualify for any new State Pension, and those with between 10 and 34 years of contributions will receive a proportion of the pension. This clearly represents an advance on old arrangements, but given the limitations outlined of Auto-Enrolment and the scaling back of occupational schemes, alongside the increase in atypical employment, it is highly unlikely that this policy change will make much a difference for those that require help. Thus, as with Auto-Enrolment, the new flat rate pension system again represents the illusion of an adequate pension, not the delivery of it.

\section{Compulsion, Non-Retirement, and Longer Working Lives}

A re-examination of the pension crisis, and also proposed solutions to the crisis allow us to understand that, for many, longer working lives will not be the product of a choice but a result of economic compulsion due to their inability to amass enough savings to retire. This directly challenges the literature that extols the virtues of extending work, and in particular the notion that flexible working will be beneficial to older workers. Indeed, it is likely to extend low pay work for those who have already endured a career of it.

This of course raises issues regarding how we deal with inequality. Recent research has demonstrated that increasingly older workers are 'performance managed' out of the workforce. ${ }^{49}$ Moreover, workers with the greatest need or desire to continue working (for example those from low pay and poor pension coverage occupations) are not necessarily those that employers are choosing to keep. ${ }^{50}$

A key problem is that Auto-Enrolment does not address the pension crisis these workers will face, as it does not cover many low paid workers, and even those that do qualify will not be able to save enough. ${ }^{51}$ A key problem is the way in which the pension crisis is predominantly presented and discussed in mainstream debates; namely that individuals do not save enough privately and are living longer than ever before. As this chapter has demonstrated, the reality is much more complex than the dominant narrative, and moreover the proposed solutions will not actually do much to relieve poverty amongst pensioners, indeed, the new policies actually transfer risk on to them, and potentially guarantee the extension of working lives. Moreover it is not expected that this situation

\footnotetext{
${ }^{49}$ I. Vickers, \& S. Manfredi, 'Age Equality and retirement: squaring the circle', Industrial Law Journal, vol. 42, no. 1, 2013, pp. 61-74; Beck, and Williams 'The (performance) management of retirement'.

${ }^{50}$ Beck, and Williams 'The (performance) management of retirement', p. 210.

${ }^{51}$ Morley, 'Rethinking the Pension', p. 3.
} 
will improve any time soon because all mainstream parties broadly favour a neoliberal approach to managing the economy, and to inform the development of pension policy. ${ }^{52}$

The dominance of neoliberal thinking in economic policy is key in explaining the push towards privatization of state pension provision (as evident in the creation of Auto-Enrolment, a public/private partnership which replaces state only provision). Specifically, it helps us understand why a fundamental rethinking of the pension system in the UK is unlikely, as any such rethink would have to directly undermine the neoliberal preference for increased privatization and transferral of risk to individuals. ${ }^{53}$ Thus questions are asked instead about extending working lives and transforming what it means to retire. The fundamental reform required of pension provision is considered beyond the realms of what is possible within the current economic environment where neoliberal economic thinking is suspicious of state involvement. ${ }^{54}$ Moreover, unless we enact policies that will ensure the protection of employment rights in older age, we are likely to see older workers 'performance managed' out of their jobs as Beck and Williams and Vickers and Manfredi have outlined. Thus we have a twofold problem; 1) compulsion to stay in the labour market rather than a choice, and 2) discrimination in that labour market impacting on the ability of certain workers to earn decent incomes (often those who require staying in labour market the most). ${ }^{55}$ What we are likely to see is greater income inequality in old age and increased pensioner poverty.

\section{Conclusion}

The focus of this volume is important to those interested in how we construct sustainable working lives, and how we secure equality for workers who face discrimination. As life expectancy increases, and retirement ages rise we are likely to see a proliferation in research investigating the various topics discussed over the following chapters. What has been offered here is a reconceptualization of the context that will frame these debates. Such a re-examination is important because work life sustainability will be an illusion for many if the choice to stay in the labour market after retirement is in fact a Hobson's choice. ${ }^{56}$

Thus if we would like to see genuine choice being exercised with regards to people's decision to stay in the labour market after the traditional retirement age, then this needs to be accompanied with access to pension schemes that will provide an adequate income in retirement for all workers. However, this seems unlikely given the current economic context as neoliberal economic doctrine which currently influences UK government prefers privatization and individualization of pensions.

\footnotetext{
${ }^{52}$ Blackburn, Banking on Death; R. Blackburn 'How to Rescue a Failing Pension Regime: The British Case'. New Political Economy 9(4) 2004, pp. 559-581; J. Grady 'From Beveridge to Turner: Laissez-faire to Neoliberalism', Capital and Class, June, 2010 pp: 163-180; Grady, 'Trade Unions and the Pension Crisis'; J. Macnicol, The Politics of Retirement in Britain 1878-1948, (Cambridge: Cambridge University Press, 1998); Morgan, 'The UK pension system'; J. Myles, Old Age in the Welfare State: The Political Economy of Public Pensions. (London: Scott Forseman and Company 1984).

${ }^{53}$ Grady, ‘From Beveridge to Turner’, 2010; J. Hacker, \& P. Peirson, Winner-Take-All Politics, (London: Simon and Schuster 2010); D. Harvey A Brief Introduction to Neoliberalism, (Oxford: Oxford University Press 2005); Morgan, 'The UK pension system'.

${ }^{54}$ Harvey, Neoliberalism; D. Harvey The Enigma of Capital: And the Crises of Capitalism, (London: Verso 2010).

${ }^{55}$ Beck, and Williams 'The (performance) management of retirement'.

${ }^{56} \mathrm{~A}$ Hobson's choice is a free choice, but in which only one option is offered.
} 
All of this, as has been demonstrated, will disproportionately affect low paid workers, who are the most likely to need to work into retirement. 